Western University

Scholarship@Western

Aboriginal Policy Research Consortium International (APRCi)

1998

\title{
Miscommunication between Aboriginal Students and their Non- Aboriginal Teachers in a Bilingual School
}

Anne Lowell

Brian Devlin

Follow this and additional works at: https://ir.lib.uwo.ca/aprci

Part of the Curriculum and Instruction Commons, Disability and Equity in Education Commons, Educational Methods Commons, and the Special Education and Teaching Commons

Citation of this paper:

Lowell, Anne and Devlin, Brian, "Miscommunication between Aboriginal Students and their Non- Aboriginal Teachers in a Bilingual School" (1998). Aboriginal Policy Research Consortium International (APRCi). 362.

https://ir.lib.uwo.ca/aprci/362 
This article was downloaded by: [University of Western Ontario] On: 16 December 2012, At: 07: 56

Publisher: Routledge

Informa Ltd Registered in England and Wales Registered Number:

1072954 Registered office: Mortimer House, 37-41 Mortimer Street, London W1T 3J H, UK

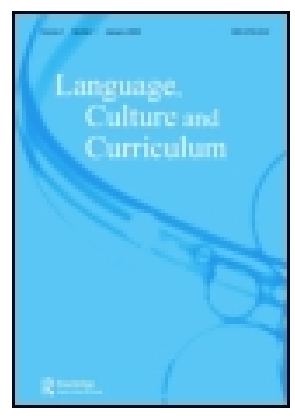

\section{Language, Culture and Curriculum}

Publication details, including instructions for authors and subscription information: http:// www.tandfonline.com/loi/ rlec20

\section{Miscommunication between Aboriginal Students and their Non- Aboriginal Teachers in a Bilingual School}

Anne Lowell \& Brian Devlin Version of record first published: $23 \mathrm{Apr}$ 2010.

To cite this article: Anne Lowell \& Brian Devlin (1998): Miscommunication between Aboriginal Students and their Non-Aboriginal Teachers in a Bilingual School, Language, Culture and Curriculum, 11:3, 367-389

To link to this article: http:// dx. doi.org/ 10.1080/07908319808666563

PLEASE SCROLL DOWN FOR ARTICLE

Full terms and conditions of use: http://www.tandfonline.com/page/ terms-and-conditions

This article may be used for research, teaching, and private study purposes. Any substantial or systematic reproduction, redistribution, reselling, loan, sub-licensing, systematic supply, or distribution in any form to anyone is expressly forbidden.

The publisher does not give any warranty express or implied or make any representation that the contents will be complete or accurate or up to date. The accuracy of any instructions, formulae, 
and drug doses should be independently verified with primary sources. The publisher shall not be liable for any loss, actions, claims, proceedings, demand, or costs or damages whatsoever or howsoever caused arising directly or indirectly in connection with or arising out of the use of this material. 


\title{
Miscommunication between Aboriginal Students and their Non-Aboriginal Teachers in a Bilingual School
}

\author{
Anne Lowell \\ Menzies School of Health Research, Darwin, NT, Australia
}

Brian Devlin

Faculty of Education, Northern Territory University, Darwin, NT 0909, Australia

A crucial question in cross-cultural education is how to bridge the cultural and linguistic differences between home and school so that a child's identity can be supported without limiting his or her chances of academic success (Eades, 1991). Various models of bilingual education have been implemented in Aboriginal communities in the Northern Territory of Australia but the implementation of such programmes is often far from ideal. In the school where this ethnographic study was conducted, miscommunication between Aboriginal students and their non-Aboriginal teachers was found to be commonplace. Even by late primary school, children often did not comprehend classroom instructions in English. In addition, many students attended school irregularly, and many had a history of mild hearing loss due to otitis media (middle ear infection) which is highly prevalent in Australian Aboriginal communities. Cultural differences in communication were not easily differentiated from hearing-related communication problems by non-Aboriginal educators. These difficulties were exacerbated by the lack of specialist support and appropriate training for teachers in cross-cultural communication and ESL teaching. Although the Aboriginal teaching assistants were often effective in minimising communication breakdown, the extent of miscommunication severely inhibited the children's education when English was the language of instruction and interaction. The problem identified is one that should be of major concern to all concerned with Aboriginal education.

\section{Introduction}

Many Australian Aboriginal children are currently denied access to successful classroom learning for a number of reasons. Some children attend school so irregularly that they have little chance of attaining hoped-for academic objectives. The factors influencing attendance are complex and range from teasing between children (Cooke, 1996) to the relationship between the school and the community, and the extent to which school programmes and teaching methods are appropriate for the students. However, even for those children who do attend regularly, the effectiveness of classroom instruction may be severely reduced due to cultural, linguistic and sociolinguistic differences between the teacher and the children. These sources of communication difficulty have been widely recognised in both urban and remote populations (e.g. by Harris, 1982; Howard, 1992; Malcolm, 1982a; Malin, 1990). Non-Aboriginal teachers working in these circumstances may lack the experience and training that would help them bridge these gaps. Communication breakdown due to such differences will often go unrecognised and the children's subsequent and inevitable lack of success in the 
classroom will often be entirely attributed to other causes such as poor school attendance.

Another potential source of disadvantage faced by Aboriginal children in the classroom is that they are at high risk of communication difficulties related to hearing loss. Studies suggest that the majority of Aboriginal children in Australia experience persistent otitis media (middle ear infection) and associated conductive hearing loss (Quin, 1988), probably from early infancy (Boswell et al., 1993). This has the potential to affect adversely aspects of cognitive and communicative development which are essential for later academic success, as well as social development (see research reported by Feagans et al., 1987; Friel-Patti \& Finitzo, 1990; Hasenstab, 1987; Silva et al., 1986; Teele et al., 1990).

As a contextual note, to help orient readers who are unfamiliar with Australia's demography, the Aboriginal population comprises 303,260 people, according to an Australian Bureau of Statistics estimate for 1994, which is about $1.65 \%$ of Australia's total, given that the estimated resident population of Australia at 31 December 1996 was 18.4 million. However, in the Northern Territory the proportion of Aboriginal people is more like $25 \%$ of the total.

The community chosen for the study reported here is located in Australia's Northern Territory (NT) where a majority of the local inhabitants are traditionally oriented indigenous people. An ethnographic study was conducted from 1990 to 1992 in a remote Aboriginal community in Northeast Arnhem Land with the aim of investigating the influence of conductive hearing loss on children's communication and learning in the classroom. Thirty children were selected for specific focus and their interactions in several classrooms were video-taped over a period of two years. Their hearing and middle ear status was monitored, informal assessments were made of their auditory processing and language development, and interviews with their teachers and parents were conducted. Aboriginal educators were extensively involved in interpretation of the data, and information from all these sources was integrated to generate the findings which have been reported in detail elsewhere (Lowell, 1994). Surprisingly, it was found that communication difficulties between children and their Aboriginal teachers rarely occurred in these classrooms, despite the prevalence of hearing loss. However, communication breakdown did occur frequently between children and their non-Aboriginal teachers and it is these communication difficulties, which are mainly related to factors other than hearing loss, that are the focus of this paper.

\section{Sources of Miscommunication in the Classroom}

As Crago (1988) has argued, cultural differences in socialisation practices and styles of communicative interaction have important implications for classroom communication and learning. The influence of cultural discontinuity between the home and school on children's participation in classroom learning has been documented by a number of investigators both overseas (e.g. Heath, 1983; Philips, 1972, 1983) and in Australia (Christie, 1984; Malin, 1989, 1990). Harris (1990: 9) was even led to conclude that 'the nature and degree of the difference between Aboriginal and European culture is so great ... that they are largely incompatible'. A number of researchers have identified substantial differences between the world view and belief systems of Aboriginal and non-Aboriginal 
people as important sources of misunderstanding in cross-cultural interactions. In Christie's (1985) account, which drew on the work of Bain (1979) in Central Australia, the world view of Australian Aboriginal peoples is described as interactional, emphasising qualities, relationships, and responsiveness to the environment, whereas the Balanda ${ }^{1}$ world view is seen as transactional; that is, rational and positivistic, focusing on manipulation of the environment. The importance of different cultural pragmatics has been demonstrated in studies of cross-cultural communication in a range of populations. For example, in a study of children from non-English-speaking educated middle-class backgrounds in American classrooms, the main source of serious miscommunication observed was conflicting expectations about classroom behaviour (Saville-Troike \& Kleifgen, 1989). Similarly, Heath (1983) reported that differences among the dialects of the US working-class black and white children she observed at home and in classrooms resulted in relatively little communication difficulty compared to differences in the uses of language with which the children were familiar.

Miscommunication resulting from a lack of shared communicative assumptions was also found in a study of classroom communication with Warm Springs Native American children (Philips, 1972). The social conditions which define when a person uses speech, and participant structures which allow for verbal interaction in Native American culture rarely occurred in the classrooms. Miscommunication therefore resulted, due to the absence of appropriate social conditions which are necessary for the required communicative interaction to occur.

Not surprisingly, cultural discontinuity between the Aboriginal home environment and the school has been proposed as one of the major factors contributing to Aboriginal school failure in Australia. Christie and Harris (1985) have argued that cultural differences between white teachers and their Aboriginal students exacerbate communication problems in the classroom. Differences in perspectives, expectations, understandings and interpretations (phenomenological differences) are one source of communication failure. There are also extensive linguistic and sociolinguistic differences between Standard Australian English (SAE) and Aboriginal languages, and between SAE and Aboriginal English.

However, McConvell (1991) challenges the validity of using world view as an explanatory variable to assert the kinds of relationship between culture, thought and language proposed by Bain and Sayers (1990), as well as by Christie and Harris (1985). According to McConvell, for example, there is inadequate empirical evidence to support their view that abstraction and hypotheticality are missing in Aboriginal discourse. He suggests (1991: 22) that it is not differences in cognition which explain miscommunication, but differences in pragmatics, that is 'rules for conveying and interpreting messages in conversation'.

Despite the recognised potential for miscommunication in Aboriginal classrooms, few studies have specifically investigated how successfully or otherwise teachers and students manage to communicate with one another. Only one research project has specifically investigated communication breakdown in Aboriginal classrooms. Malcolm (1982a, 1982b) reported on an extensive investigation of 24 classrooms in schools which ranged from $12 \%$ to $100 \%$ 
Aboriginal enrolment. 115 sessions were recorded in the classes of 99 different teachers, representing all primary (elementary) grades as well as ungraded and withdrawal groups. Three levels of communicative dysfunction were identified: linguistic incompatibility, linguistic interference and sociolinguistic interference. Examples of linguistic incompatibility included an inability to retrieve information from the linguistic context, a failure to make or to hear subtle grammatical distinctions and unfamiliarity with the teacher's vocabulary. In areas where Aboriginal languages were in regular use by children, the linguistic system with which the child was most familiar was thought to be incompatible with the linguistic demands of the school. Linguistic interference was thought to be the result of a number of influences, depending on the languages known by the child, and was said to occur on a number of dimensions, including the phonological, syntactic, lexical and semantic. Malcolm (1982a) suggested that sociolinguistic interference stemmed from four key areas of divergence between Aboriginal society and European society in the school domain. These areas of divergence included the nature of the speech community, the place of knowledge, patterns of respect and deference, and patterns of receiver and audience behaviour.

As in the studies on Native American classrooms (such as Erickson \& Mohatt, 1982), Malcolm (1994: 166) found that the teacher and the pupils 'operate under particular communicative constraints which bear upon the way in which they use language and the way in which they understand one another'. Predictable and definable differences were observed between the classroom discourses in which Aboriginal pupils were participating and those involving European Australian children. Four major sources of communicative difficulty were identified through an analysis of the discourse structure: 'incomprehension on the part of the teacher and pupil, incompatibility of communicative terms, instability in the communicative setting, and indeterminacy of teacher approaches' (Malcolm, 1994: 167).

Insights into classroom communication have also emerged from other related studies (Malin, 1989,1990; Walker, 1983). Differences in length of pause time were found to be a source of miscommunication by Malcolm (1979) and Malin (1989), and differences in expectations about, and obligations for, listener response have also been described by Harris (1977) and Kearins (1985). Walker (1983) investigated the English brought by Aboriginal children from backgrounds of varying traditional orientation to their formal schooling; his aim was to adapt and develop the curriculum to suit the special needs of these children. Language samples were collected from each child within four different school situations: recess (in the playground), free time (within the school building), classroom teaching, and language unit teaching. An analysis of the language samples collected in the first two situations indicated that the children had sufficient mastery of a dialect of English to communicate effectively with their peers in informal, out-of-school situations. However, both the purposes for which they predominantly used language and the range of semantic and related syntactic categories found within their utterances were reported to be restricted compared with those identified in the speech of non-Aboriginal children of similar age. It is important to note that these categories were derived from a non-Aboriginal perspective on communication development: the potential cultural bias inherent 
in such an approach might have contributed to the interpretation of deficit, rather than difference in the children's communication development. Walker (1983) did stress that the children's English was highly functional and sufficient within the contexts in which they needed to use it and that the 'restricted' system described did not reflect a lack of capacity to think or learn in other ways. Walker concluded that current school programmes are unsuitable because they are based on mistaken assumptions about how children learn language and suggested that basic changes would need to occur in the programme and teaching strategies if these children and their teachers were not to face serious and fundamental difficulties. The findings of the study reported here indicate that such changes have not been implemented. The serious and fundamental difficulties predicted by Walker are still in evidence.

Listening and attention are central concerns in classroom interaction and the pragmatic features of receptive communication could be expected to be culturally determined. Accounts of cultural differences in listening behaviour and indicators of attention are few but important differences have been identified between some cultures. In the literature on Aboriginal communication, however, this area is rarely addressed. Harris (1977) noted that the behaviour of Milingimbi Yolngu Aboriginal listeners during a public speech did not involve passive immobility and constant staring at the speaker, but what in Balanda terms would be considered 'restlessness'; he suggested that there are also differences in expectations about, and obligations for, listener response. Yolngu speakers use a number of linguistic forms to elicit responses in conversation, but since listeners are not obliged to respond, response avoidance is not cause for embarrassment. Differences in listening behaviour have also been reported in the classroom: Yolngu children may be physically active when listening to a story which they understand, and which is being read by someone with whom they are relaxed. This would be interpreted as lack of interest and inattention from a Balanda perspective, but Harris (1977) recounted a teacher's comment that students retained more detail of the stories he read to them than he would have expected given their restless behaviour.

The observation that Aboriginal people show few signs of attending, even when they are actually listening, was also made by Webber (1978). Rules of avoidance related to kinship, as well as different cultural expectations regarding audience participation, have been suggested as factors which contribute to differences in listening behaviour (Harris, 1977; Webber, 1978). The freedom of Aboriginal children to behave independently is another factor which may contribute to differences in listening behaviour (Harris, 1977; Kearins, 1985). Kearins (1985) suggests that Aboriginal children are not taught to signal their attention to adult instructions by answering immediately, which is the expected behaviour of Western children. She attributed this to difference in cultural attitudes to human control, and suggested that school-aged Aboriginal children will probably not have developed the same verbal strategies as non-Aboriginal children, and will not have been trained to 'listen' on demand.

Definitions of attention often focus on indicators of visual attention, without acknowledging that auditory attention can be maintained without any visible indicators. For example, in a study of attention during reading lessons the 
criterion for attention was whether the student was looking where he or she was supposed to look at that time, but it was stressed that the definition of attention must be social and normative (Imai et al., 1992). However, as Webber (1978: 64) suggested, although 'looking usually implies listening if people are close by, listening does not necessarily imply looking' in Aboriginal interaction.

Erickson and Shultz (1982: 179), in their US study of interviews between college counsellors and students, found a 'mismatch between the listener's cultural style in the performance of listening behaviour and the speaker's cultural expectations for the kinds of listening behaviour to be performed'. Differences in listening responses between Blacks and Whites were marked in their sample: in the white cultural style, listening response was given with broad behavioural emphasis, often verbally and nonverbally at the same time, that is, a verbal backchannel accompanied by a head nod. Listening response by Blacks was much more subtle: when black listeners were listening to black speakers they used only a verbal back channel, without any nod. They found that in the white and black cultural styles of explaining, and listening while being explained to the points of behavioural emphasis were opposite. As a result, black listeners tended to miss the subtle cues of white speakers calling for a listening response; and white speakers tended to miss the relatively subtle listening response cues provided by black listeners.

Erickson and Mohatt (1982) compared the different ways in which Indian and non-Indian teachers interacted with children in classrooms at an Odawa reserve in the US. Among the culturally patterned differences they found were varying expectations about what constituted 'paying attention', as well as how to manage and reinforce attentional behaviour. Differences in the listening behaviour of students during lectures were also found in South Africa for Zulu students who spoke English as a second language, compared to Asian and 'Coloured' students who spoke English as a first language (Chick, 1989). In the few Australian Aboriginal studies that mention listening, such as Harris (1977), Kearins (1985) and Webber (1978) cited above, it is assumed that if listeners do not show the visible signs of attention which are expected in non-Aboriginal interaction, then they are not considered to be listening. Consideration of possible cultural differences in listening behaviour is essential if valid interpretations of communicative interaction are to be made, and further investigation is required to clarify and document the features of listening behaviour in Aboriginal communication.

The potential for misunderstanding is not restricted to interactions between traditionally oriented Aboriginal people and non-Aboriginal Australians. In a study of urban Aboriginal children at home and in the classroom, Malin (1989) found that the skills and characteristics which were valued at home by Aboriginal families were not valued in class. Differences in ways of communicating were also a source of misunderstanding between these Aboriginal children and their non-Aboriginal teachers. For example, it was expected in Aboriginal families that the children would be both autonomous and affiliative. However self-directed, autonomous behaviour, far from being valued in a mainstream Balanda class, became a source of conflict, as it was sometimes interpreted by the teacher as disrespect (Malin, 1989). In one classroom these differences, which were coloured by the teacher's low expectations of the Aboriginal students, resulted in a serious 
lack of rapport between teacher and student. The other sociolinguistic differences that were thought to contribute to the classroom difficulties experienced by these children are similar to those which have been identified by other investigators; these include the different understandings teachers and students had about the appropriateness of asking questions, and how to frame them, a finding which is consistent with Eades (1982); variations in the length of pauses considered appropriate, as found by Malcolm (1979); and the degree of comfort or discomfort in performing in public, an aspect of interactional behaviour which has also been discussed by Harris (1977). A disturbing observation in this study was that, on many occasions, the Aboriginal students' verbal contributions were not understood, or even recognised, by the teacher (Malin, 1990).

Walsh (1996) has proposed one way of conceptualising pragmatic differences between Aboriginal and non-Aboriginal communication. In his model of participant relations, Balanda-style talk is dyadic. Conversational practices are governed by an ideology of talking in twos. Talk is commonly directed to a particular individual and among the implicit assumptions about how one should hold a conversation are that people should face each other, that eye contact is important, silence is to be avoided and that the speaker has some control of the interaction. Such generalisations, however, do not accurately describe how people interact with one another in Aboriginal communities and households. Talk is broadcast. People need not face each other when they speak. Eye contact is not important. Silence need not be avoided. Control of an interaction is maintained by the hearer.

From an Aboriginal perspective interaction is regarded as continuous, as if the communication channel is 'turned on' and left on, but non-Aboriginal interactants are more likely to regard it as contained. As Walsh (1996) explains, talk is packaged into discontinuous bits. The communication channel is 'switched off' explicitly, which allows one to say something like 'I can't talk now'. This approach is foreign to an Aboriginal person who has learned to handle the continuous broadcasting of talk by tuning in and tuning out as needed. For children not to answer a question is perfectly acceptable in a continuous-communal style of interaction but the Anglo teacher is likely to find it a bit hard to take. Another implication of these contrasting interactional styles is that while 'Yes' may mean agreement to a speaker used to contained-dyadic communication, an Aboriginal interactant may simply understand it to mean 'I'm still tuned in', 'I'm still listening'.

This model provides a useful framework for understanding the features of communication and communication breakdown identified in the study of classroom interaction described in the following section.

\section{The Study Community}

The research was conducted in the classrooms of a bilingual school in an Aboriginal community in Northeast Arnhem Land in the Northern Territory (NT) of Australia. The study community has a population of approximately 1500 Aboriginal people, who refer to themselves as Yolngu and around 50 non-Aboriginal people (Balanda). Yolngu clans are interlinked by marriage and kinship ties, each identified by a particular area of land, and characterised by its own 
variety of Yolngu Matha, the family of languages spoken in the region. The complex kinship system, called gurrutu, continues to structure all relationships, and subsequently has a profound influence on interaction in all areas of community life, as well as in the classroom. In this traditionally oriented community the children speak one or more Yolngu languages and English has little relevance in everyday interactions. Many children are exposed to more than one Yolngu language in common use at home, but most acquire as their first language Djambarrpuyngu, a clan language which has become the lingua franca in this community. Djambarrpuyngu is the language used in the school as well as for most other purposes in the community, including the clinic, store and council. Children are also expected to acquire their fathers' clan language as they get older, although there is some concern that this is generally not happening for clans other than Djambarrpuyngu (Devlin, 1986). In this region a sign language is also widely used to fulfil a number of communicative functions, including communication over distance or when silence or privacy is required (Cooke \& Adone, 1994). It is often used in the classroom by Yolngu educators as part of their communicative repertoire, as well as between children who do not want to be heard by the teacher.

The school officially conducts a bilingual programme. According to the model on which the programme is based, Djambarrpuyngu is the main language of instruction in the early years and the use of English is gradually increased until it becomes the predominant language of instruction in the final years of primary school. There is a pre-school, primary and post-primary section with an approximate enrolment of 400; however, attendance varies and is generally between half and two-thirds of enrolment.

The majority of the trained teachers in the school in the past have been Balanda. Although the number of trained Yolngu teachers in the community has been steadily increasing, the number of Yolngu teachers working in the school varies from year to year. Yolngu teacher assistants (TAs), who do not have formal training, work in the primary school alongside Balanda classroom teachers. At the time of the study no specialist ESL teaching positions had been allocated to the school, even though none of the children spoke English as a first language.

In 1990 a survey of the hearing and middle ear status of 180 children in the school found normal middle ear states in only $30 \%$ of children's ears, and $46 \%$ of the ears tested were found to have some degree of hearing loss (Nienhuys et al., 1994). As the prevalence of middle ear disease is highest in early childhood even the children with normal hearing by school-age could be at risk of communication and learning difficulties due to their previous hearing loss. Despite this, none of these children had received effective medical or audiological management for their hearing problems. In addition, provision of appropriate educational support services, such as special education, educational psychology and speech pathology was limited or non-existent in the community. Staffing levels did not reflect either the ESL status, or the special needs status, of the children in the school. For example, in one year during the study the Transition class had an initial enrolment of 50 children, the majority of whom had a current hearing loss. However, the class was staffed by a single inexperienced teacher, who had only recently graduated. 
The factors which impact on children's communication in the classroom in such a context are complex: the majority of the children have past or present hearing loss with potential developmental consequences, and there are extensive cultural and linguistic differences between the Balanda staff and the children they teach. This paper does not attempt to account comprehensively for all sources of communication breakdown in these classrooms, but simply identifies some features of interaction and language instruction which seem pertinent. One particular source of miscommunication, pragmatic differences in listening behaviour, is explored in greater detail.

\section{Overview of Interaction in Yolngu Classrooms}

According to the formal structure of the bilingual programme at the school selected for this study, Yolngu Matha is the initial language of instruction and the role of English is gradually extended at each year level. Initial literacy is therefore in the vernacular language and English literacy is introduced in the middle primary years. The reality in the classrooms, however, does not always reflect this preferred 'staircase model' (referred to locally in the NT as the Model 1 programme). For example, when there is no TA present, instruction is, by necessity, predominantly in English even at Transition level. In the later years of primary school, when teaching and learning activities should be mainly in English, Yolngu Matha is often used, overtly or covertly, simply because the children do not understand sufficient English for effective communication to occur.

It has been argued that the most powerful determinant of minority children's interactional behaviours in the classroom may be the structure of the communicative situation, rather than the influence of cultural background (Malcolm, 1989). 'Participant structure', as it is now frequently termed, is one of four important concepts which Malcolm has identified in the research on communication problems in cross-cultural classrooms; the others are patterns of organisation, balance of rights and cultural congruence. The relevance of these concepts was clearly evident in the way Aboriginal TAs and Balanda teachers play out their roles and relationships in classroom interactions. When a Balanda teacher was assisted by a TA, communication with students was generally more effective than when the Balanda teacher worked alone, but the extent of this advantage varied, depending on the approach used. Some Balanda teachers adopted a collaborative approach, planning their lessons with the TA, who then gave most of the instruction in Yolngu Matha or sometimes in English in the later grades. Other Balanda teachers took more direct responsibility for their own teaching and sought assistance from the TA when they were aware that it was needed; for example, at times when obvious communication breakdown was occurring. Some TAs provided the necessary support without being asked; others accepted a more passive role.

One teaching assistant, who had actively prevented and repaired communication breakdown as it occurred in her class, left during the study and her former team-teaching partner, the Balanda teacher, became frustrated when the new TA did not translate for the children, as the previous teaching assistant had done. Another TA had to accommodate three changes of Balanda teacher in one year. 
She explained the difficulties she experienced while working with one of these teachers:

We should plan together activities for next day [but] she was just leave work just with me $g a$ ('and') she was just sitting ga doing nothing. I told her to plan together for next day but baayngu ('no') she didn't help me for next day. (Audio-tape G1:A.9)

In the past, some training was provided to Balanda teachers and Yolngu teaching assistants (TAs) to help them work together, but this no longer occurs. There is an evident need for more in-school professional development support to develop the skills required for effective collaboration and negotiation between Balanda and Yolngu staff.

Miscommunication was most frequently observed when a Balanda teacher interacted with the children in English, and the lessons that were video-taped do provide some evidence of what Malcolm (1982a) termed linguistic incompatibility. However, the Balanda teachers were not always aware of communicative difficulties when they arose and therefore did not seek to repair the breakdowns. The TA, or sometimes the children who knew some English, would often repair such problems by translating or clarifying the Balanda teacher's instruction. This often went unnoticed by the teacher. An example of this also occurred when the first co-author was conducting small-group assessments with $\mathrm{N}$. When she reviewed the video-tape she realised that, while she had been talking to the children in English about a book, $\mathrm{N}$ had been translating her comments into Yolngu Matha (video-tape G2-1.8), but she was not aware of this at the time.

Instances of communication breakdown occurred most frequently when a Balanda teacher attempted to communicate directly with the class in English without the assistance of the Yolngu TA. In one of many such examples, K was conducting an activity in English (Video-tape G1-1.10). B, the Yolngu TA, was sitting some distance away behind the children, who were on the mat in front of the Balanda teacher. The children did not respond to questions and were clearly having difficulty understanding $\mathrm{K}$. When reviewing this video the TA explained that she was quietly helping the children at the same time even though the teacher did not ask her to sit with her and help. This Balanda teacher either did the activity herself, or told the TA what to do; the cooperative interaction that the TA enjoyed with other teachers was not evident in classroom observations involving $\mathrm{K}$. B described the importance of this cooperative approach for ensuring effective communication:

$\mathrm{R}$, she's manymak Balanda ('a good European teacher') because when she did her activity she always need me to help her to help her tell in Yolngu Matha; $\mathrm{K}$ don't ask me to sit with her $g a$ tell me to tell them in Yolngu Matha that's why children don't understand ... what she's talking about. (Audiotape G1:A.9)

The children's difficulties with basic English, and the important role of the TA in facilitating effective communication, were again demonstrated during a mathematics activity (Video-tape G1-1.11). The teacher asked the children to identify the objects that she requested from a collection of shapes which differ in 
size, shape, colour and thickness. Few children were able to respond correctly as they did not appear to understand the terms used to describe the objects' attributes, and they also had difficulty with the terms 'same' and 'different'. The teacher attempted to explain these concepts, drawing on her limited Yolngu Matha vocabulary, but without success, so she finally sought help from the TA who said: 'when she's stuck with these children she asks me to explain [to] them - it's her activity; [children] feeling boring because she's speaking in English so they are boring ga tired'.

When asked if the children were listening, the TA responded emphatically:

BAYNGU (not at all) because she's speaking in English yo ('yes') you see? Can you rewind it - see that, $\mathrm{K}$ trying to move them from the circle,see, but they're not moving; they don't understand she move them [even though she is using gesture]; she told me to move them.

B was quite definite about what would be the most effective approach for Balanda and Yolngu staff to use in the classroom: 'the best way is working together'.

While it is valuable to understand the role relationships of the staff in the school selected for this study, the focus of this paper is on the dysfunctional communication which was evident in the classrooms that were observed. Malcolm (1982a) attributed difficulties of this kind to 'sociolinguistic interference' and identified differing expectations of receiver and audience behaviour as one key area of divergence between Aboriginal society and European society in the school domain. One of the Yolngu teachers observed in this study described some of the difficulties faced by the children and for herself in interactions with Balanda:

for Balanda they can see just children - they expect that child to listen to her, talk to her whenever she's told, and she want quick answers - bondi, bondi ('quickly'). I find, as a Yolngu teacher, whenever there is questions given to me or said or whenever there is any big, this is just ngarra ('me'), any issue or any lesson beginner lesson - it takes time for thinking for Yolngu kids. This is what I find - it will give time for me to think ga how to express it or how to say it in a correct way. (Audiotape G2:A.1)

To draw on the contrasting interactional styles model suggested by Walsh (1996), it is as if the non-Aboriginal teachers package talk for their class and expect packaged answers in return, whereas the Yolngu students prefer to manage their own responses in their own way and at their own pace, preferring communication that is continuous rather than contained.

Many instances of communication breakdown were observed when the language of instruction used was English and this happened with all the Balanda teachers in all the classrooms, but with varying frequency, depending on the presence and involvement of the Yolngu staff, and the level of the relevant linguistic and sociolinguistic knowledge of the Balanda teachers. However, communication breakdown occurred even when experienced Balanda teachers were working effectively with a competent TA. An example of this occurred when the teacher, the TA and the children in Transition were discussing a football 
grand final (Video-tape G1-1.2). The Balanda teacher started the discussion by asking in Yolngu Matha (not English) 'Who went to the game?' and received an enthusiastic response from most of the children. She then switched to English and the children appeared not to understand so she switched back to Yolngu Matha. Again most of the children responded. The teacher asked B if the children knew what had happened the day before the final. While B talked to the children about it, they all kept moving around and fidgeting except at one stage when they all focused on her as she asked a question. B explained later that she was asking about the music before the match and they stopped moving around because it was a hard question. The Balanda teacher, $R$, then started to describe in English the feast held the night before. The children initially all stopped moving around so much and looked at her. They seemed to have difficulty understanding the language she was using and gradually appeared to lose interest. B then asked questions about the game in Yolngu Matha: the children all responded and enthusiastically participated in the discussion.

A little later the Balanda teacher asked a child who he supported and he was assisted by another child $(\mathrm{Dj})$ who was more familiar with English. When she reviewed the video-tape, B explained what happened: ' $R$ [the teacher] asked $G$ who he was supporting, and Dj said "nha, Ngayawili?" [to cue the child who was asked the question] then I asked [the same question] in Yolngu Matha ...' It was common for one child to help another by modelling an appropriate response and for the Yolngu TA to translate English into Yolngu Matha. These as well as other strategies used by children and teachers to minimise miscommunication are discussed in the next section.

\section{Strategies Used to Repair/Prevent Communication Breakdown}

Strategies such as translating Yolngu Matha into English, modelling correct responses and code-switching were commonly employed to minimise and/or repair communication difficulties which occurred when English was being used for instruction. In all the classrooms, children with the greatest knowledge of English provided such assistance, by modelling the answer or by translating the teacher's utterance, when the other children did not understand. B commented on the communication strategies used by a Balanda teacher who often spoke to the children in Yolngu Matha:

Researcher:

B:

'Does it help?'

Gangga - [a] little bit. If she can speak in English some children can understand $g a$ ('and') some baayngu ('not at all'), when she can speak in Yolngu Matha they can understand.

(Audiotape G1:A.8)

Although such code-switching is considered unacceptable according to the model of bilingual education on which the school programme is said to be based, in practice it was sometimes thought essential to use it to achieve effective communication in the classroom. Examples of this kind of pragmatic codeswitching were often observed, particularly in the earlier primary grades when the TA was absent. One such incident occurred during a colouring activity in the 
Transition classroom. R, a Balanda teacher, asked Ga where her English work was but received no reply. She asked again, this time in Yolngu Matha and Ga showed her the work in question. $\mathrm{R}$ then gave the next instruction in Yolngu Matha (Video-tape G1-5).

Such code-switching was not only used by the Balanda teachers. Yolngu teachers often mixed languages in different situations. Sometimes they needed to use words from one language that they did not know, or that did not exist, in the other language; at other times it was a purposeful strategy to facilitate comprehension and language learning. In one classroom the TA used both Yolngu Matha and English (G1-1.3) and the children were very responsive. N explained why she did this:

gangga ('a little bit' — understanding of Balanda teacher's English); some understand, some baayngu ('don't understand.) You see I'm talking both: Yolngu, English ... (Audiotape G1-A.13)

The Yolngu teachers explained that, when children do not respond to a Balanda teacher's questions, they assume that the children do not understand, and so they assist them by talking in Yolngu Matha, or sometimes in both languages. The model proposed by Walsh (1996), however, suggests that the miscommunication may sometimes be due to sociolinguistic rather than linguistic incompatibility. On occasion it could be the differing interactional styles of teacher and student, rather than lack of English comprehension, that give rise to silences instead of the expected intelligible responses.

Not only the children in early primary, but also the older children who had been attending school for five or more years appeared to have difficulty with English comprehension, even when the TA was there to provide additional support. For example while one Year 4 class was being observed there were instances of communication breakdown during the reading of an English story (Videotape G2-7). G, the Yolngu TA, read a story about baby turtles in English, then gave the children further explanations in Yolngu Matha. The children began to comment on the story and to ask questions in Yolngu Matha. $\mathrm{K}$, the Balanda teacher, then started asking questions in English at which point most of the children seemed to have difficulty understanding and responding. For example, K asked, 'Who got tricked?' and the children answered 'turtle', which was not correct. K then attempted a repair by rephrasing the question: 'Who did he trick?'. $\mathrm{K}$ continued to ask questions about the story with $\mathrm{G}$ participating only to translate. Some children responded when G spoke in Yolngu Matha, but not when $\mathrm{K}$ used English. The children seemed to refocus on the task when $\mathrm{G}$ repeated K's questions in Yolngu Matha. The children finally seemed to lose track and showed no sign of understanding what $\mathrm{K}$ was saying in English about the punch line of the story. In contrast, when G asked 'Nha rirrakay?' ('What sound?') the children all called out the sound that she had used for the turtle when he escaped during the telling of the story.

When the activity changed, the communication difficulties continued. K said to the children: 'Nothing in your hands, looking this way ... watch'. When the children didn't comply, G spoke to them in Yolngu Matha and they all looked towards $\mathrm{K}$, who then gave a long instruction in English, asking the children if 
they had been doing handstands in the dirt and suggesting that they should wash their hands. The children did not respond and most of them kept looking towards $\mathrm{G}$ who seemed to be attempting to clarify in Yolngu Matha. However, $\mathrm{K}$ continued talking so they looked back at $\mathrm{K}$. When she finally finished speaking, $\mathrm{G}$ translated what $\mathrm{K}$ had said and, immediately, the children all looked at their hands (Videotape G2-7). During this session the TA frequently used repair strategies, including translation and clarification, when she realised that the children did not understand the Balanda teacher. This assistance was not often requested by the Balanda teacher, who did not appear to recognise, or attempt to repair most of the instances of communication breakdown that occurred.

\section{ㄱ Limitations of the English Programme}

The focus of the English programme in most of the classrooms was on English literacy even though the children had very limited oral English skills. In the first year of the study, no oral English activities were observed during the periods of video-taping until second semester, when a breakfast programme which incorporated oral English dialogues was introduced in some classrooms. English teaching activities were predominantly literacy based, including activities such as the reading of English story books aloud, and the reading of flashcards. English songs and nursery rhymes were also used in the early primary years.

When the teaching of oral English was discussed with the teachers, most commented that they did not follow a formal English curriculum, but taught it incidentally. Reading of books aloud was often cited as an oral English teaching activity. In the Breakfast Programme dialogues, the question-and-answer sequences were often inappropriate and did not reflect normal communicative interaction. For example, the range of response options children were given to the question 'How are you today?' included 'I am happy' and 'I am hungry'. In this Year 1 classroom, children were also required to respond to the question 'What is your name?' before they were given their breakfast. This is both communicatively and culturally inappropriate in this context: the children were aware that the teacher already knew their name. Yolngu children are also extremely reluctant to say their own name when asked and it is usual for a third person to give this information. Later in the year, in the same classroom, the set of questions became: 'What's your name?', 'Where do you live?', 'How old are you?', 'When is your birthday?', 'What school do you go to?', 'What class are you in?' and 'What class are you going to be in next year?'. Even children who were normally quite confident and responsive had great difficulty with this sequence (Videotape G1-1.10).

Other examples were a little more relevant to everyday communication, such as 'What do you want on your Weetbix?', 'I want milk and honey on my Weetbix', but this interchange was used continuously over many months, without extension or generalisation of the language function or forms. In other instances, the dialogue changed so dramatically that the children became confused. S described what happened when she changed the dialogue in Year 1:

[Wamuttjan] was understanding everything but when I developed a new set of questions - a longer set but the same questions, three or four extra 
ones on the end she just lost track and at first we were going through the same questions in the same order everyday so that it was very repetitive even that she just couldn't keep up with - even the first question 'where do you live' ... (Audiotape G1:A.3; teacher interview)

One Balanda teacher said that she was not aware of any formal ESL programmes that were available. She based her classroom programme on ideas from her reading and from one of the other teachers, and she felt that more specialist ESL support would be an advantage. She said that in her Upper Primary grade only four children knew any oral English at the start of the year. Although none of the children in the school spoke English as a first language, there was not a specialist ESL position allocated to the school and none of the teachers had ESL teaching qualifications. There is one ESL adviser based in the regional centre whose role is to provide support to all the schools in the region. However, during the period of the study, the adviser visited the school very infrequently.

The view that the bilingual programme was not working was often expressed by both Yolngu and Balanda staff. Occasionally it was acknowledged that this may have been because the programme was not being implemented well. Often, teachers commented that in 'mission days' the children learnt English more successfully. Some of the Yolngu educators said it is important that Yolngu staff do some of the English teaching to provide a role model for children. N commented that:

what I find is: it's manymak ('good') for Yolngu to be in the classroom to speak in English that's how they (children) will understand [and] know that Yolngu can speak English; without a Balanda I can take them for oral English; I can teach them to say 'Good morning, can I have Weetbix' or 'May I go to the toilet?' I can teach [English] to make them understand and to make them feel happy that Yolngu can speak English, eh? (Audiotape G1:A.13)

In almost all of the observations of oral English teaching, the use of English was by rote, the content was generally inappropriate for the children's communicative needs, the range of language functions was restricted, and there were no opportunities for generalising language forms that were introduced. The TA in another upper primary classroom described the English programme as memorising sentences from a book, then doing a written activity on a worksheet. There was no longer any oral English instruction done in that classroom. By Upper Primary, according to the model on which the bilingual programme was based, most of the instruction should be through English and yet the children did not have, and were not being taught, the oral communication skills in English essential for effective participation in classroom interaction. Repeatedly, teachers were observed to be attempting to teach children curriculum content using oral English that the children did not understand. As a result, miscommunication was frequent, and opportunities for effective learning were seriously diminished. 


\section{Listening and Attention in Yolngu Classrooms}

Listening emerged as an important feature of classroom communication for both Balanda and Yolngu teachers. As might be expected, given the high prevalence of hearing loss in this population, receptive communication difficulties were a serious source of potential difficulty for some children. However, this was also the aspect of communication which was most often misinterpreted. Cultural differences in listening behaviour, as well as individual differences, were a common source of confusion in the classrooms, and the importance of differentiating between cultural differences in listening behaviour and listening difficulties became increasingly apparent.

One of the most common aspects of classroom behaviour about which the teachers comment is whether or not a child 'pays attention'. A child's level of auditory attention is usually judged by a number of indicators, such as physical orientation towards the teacher or current task and eye contact, as well as their level of distractibility and restlessness. As discussed above, differences between Aboriginal and non-Aboriginal listening behaviour have been reported, such as less expectation of visual attention and kinesic indicators of attention, and less obligation for the listener to respond quickly, or at all (Harris, 1977; Kearins, 1985; Walsh, 1996; Webber, 1978).

In the classrooms observed in this study, many children consistently exhibited behaviours that, using non-Aboriginal cultural criteria, suggested that they were not listening. These children were constantly moving, lying down, fidgeting, using Yolngu sign language to tease other children, looking towards any other activity occurring inside or outside the classroom, or appearing generally uninvolved in the current task. However, their responses to the teacher's questions or instructions showed that they must, in fact, have been attending to the teacher's message. Clear differences were often apparent between the 'listening behaviour' expected from the children, depending on whether the teacher was Yolngu or Balanda. Some of the Yolngu teaching staff also seemed to encourage children to 'look like they are listening', particularly when a Balanda teacher was conducting the lesson, but this was not always the case. G, a Yolngu TA, was questioned about an incident during a lesson in the Upper Primary classroom (Videotape G2-1.4), and she was adamant that she was not attempting to modify the children's behaviour because of the presence of the Balanda teacher:

Yaka, baayngu ... I didn't pretend just to let L see that they are listening, I was just talking to the kids ... I know what I am doing ... I am happy [with the children's listening]. (Audiotape G2:A.12)

G explained that she asked the children to 'listen' using the English word only to signal that they must attend to her as she was about to read them a story, and it seems she expected auditory, not necessarily visual, attention. G sat on a small chair close to the children who were on the mat, and throughout the story reading the children lay down, moved around or wrote on their worksheets. Although they did not appear to be attending to the story from a Balanda perspective $G$ was quite sure they were listening effectively and did not feel any need to modify their behaviour. 
The pragmatic differences in signalling attention described above are also apparent in interaction involving Yolngu adults. For example, if they appear to shift their focus of attention to another input it does not mean they are no longer listening as their recall of the message, sometimes many months later, demonstrates. In Balanda communication such a shift would signal that the listener is no longer listening. The model proposed by Walsh (1996) provides one helpful explanation of why this might occur. Such cultural differences in pragmatics, which have also been described by others such as Harris (1977) and Webber (1978), are therefore a potential source of misunderstanding in interactions between Yolngu and Balanda. Differences in selective attention - the ability to focus on one aspect of auditory input while ignoring others - are also apparent. Yolngu adults explain that they are able to listen to a number of conversations simultaneously, and children also appear to develop this ability. Whereas the ability to screen out extraneous noise is seen as a desirable skill in the Western context, evidence from the classroom observations and discussions with the Yolngu educators indicates that the ability to attend to, and process, multiple auditory inputs is encouraged in Aboriginal children. This is consistent with the suggestion that Aboriginal people may be more likely to employ a simultaneous rather than a serial method of synthesising perceptual information (Davidson, 1979). Differences between the listening behaviour of Aboriginal children at Maningrida and non-Aboriginal children are described in an information booklet for teachers:

When they [Aboriginal children] listen to stories, they don't sit quietly and look at the story-teller in the way that non-Aboriginal children are expected to behave. They are often listening even when they are talking and playing around ... (Northern Territory Department of Education, 1989:3)

It is, therefore, not surprising if children have trouble sitting still, quietly watching the teacher, if such requirements are not congruent with their customary listening behaviours. It may, in fact, be counter-productive to encourage 'selective attention' in children who have a well-developed ability to process effectively more than one auditory stimulus simultaneously.

Both the ability of Yolngu children to listen without appearing to be attending, and the ability to attend to multiple auditory signals, are described by $\mathrm{M}$ :

if they not listening $g a$ looking at that person - even though they are not watching they can hear whispering - she can still hear what they said even if there is lot of crowd talking - can still hear - even if [there is] dharrwa ('a lot') noise around still they can hear what you said. Every person that said something at the same time - he or she can hear (them).

$\mathrm{M}$ explained that, even when there are other noises in the classroom they do not necessarily interfere with effective listening:

when someone, or I'm talking, or other person talking at the same time in the classroom - straight away I can hear - ngarra ga other djamarrkuli ('I and the other children') can hear at the same time - if they one person talking, ngarra ga (I am) talking, other person in next room, or plane are flying across or someone driving (i.e. outside noises). 
When we watched a section of video, during which one of the teachers was using a staple gun while $\mathrm{M}$ was giving the lesson, $\mathrm{M}$ was asked if this distracted the children. She said 'baayngu' but explained that younger children might be distracted. She described differences in the listening ability of children at different year levels:

[Year 3] ga up - they can get that concept; little ones can easy forget djamarrkuli too noisy: can't listen to each other; by year 3 manymak - can pick up anything - even though they talk so fast they can still pick up. (Audiotape G2:A.6)

Other people also talked about the way Yolngu could be listening even when they appeared not to be attending, and about their ability to listen to more than one conversation at the same time. In one section of video taken in the Year 1 classroom, the children were very restless and appear not to be listening while the TA was telling a story in Yolngu Matha, but when she asks a question about the story most of the children put up their hands and their responses are correct. The first co-author reviewed this section of video a number of times and each time she initially interpreted their behaviour as inattentive. It seemed to be such a clear illustration of children not listening to the teacher, until she observed their responses to her questions at the end of the story. She asked $G$ for her interpretation of this section of video who described her reactions when she watched it:

$B$ is asking questions about the story — that was right answer; two different words but right answer - galun, gapu;. (At first) ngarra thinking — they weren't listening; then I think they are listening by ear — not seeing — but concentrating with their ear, but not with their eyes.

$\mathrm{G}$ also described the variations in listening behaviours exhibited by the children:

walal marnggi ('all of them know') - same time nhaama ('look at') picture - wiripu nhaama ga wiripu yaka nhaama, eh? ('others look and others don't look') but walal ga nhaama dhaawu ('all of them are listening to the story'). (Audiotape G2:A.10)

To further illustrate these features of Yolngu listening behaviour, $\mathrm{G}$ recounted a recent incident in which her young son was playing nearby while she and some other women were 'telling stories'. She was surprised when he later asked questions about what they had been saying because it seemed to her that he was not listening. She said that in the classroom children can be talking to other children and not watching but sometimes they were listening: 'children can tell stories and listen to the teacher' (at the same time). I then asked her about how Yolngu adults listen and she gave this example:

if I invite my friends and my husband is telling stories to other person I can talk with my mouth ga lips and sound come out from my mouth but I can concentrate with my ear on what my husband is saying - then stop then ask a question: 'Can you rewind that story again for us?' because I was listening one ear to him and also my body and my mind concentrate to my 
visitor, but my ears concentrate with other — balanya (like this) skills of [Yolngu]. (Audiotape G2:A.10)

Misinterpretation of listening behaviour by Balanda, that is confusion between difference and deficit, occurs easily due to a lack of understanding about cultural differences in communication. The discrepancies between the Yolngu and Balanda perceptions of one Yolngu student's listening are one example of this. Concerns about this student's listening were expressed only by Balanda teachers, and attempts to modify his listening behaviour were made only by Balanda teachers and not by the Yolngu teacher assistants. When the student's listening was discussed with his teachers the Yolngu TA said his concentration is 'manymak' (good) but his Balanda teacher said that 'he doesn't concentrate well' (Audiotape G2:A.5). Analysis of the video-tapes indicates that, from his responses to questions and instructions, he is attending consistently and effectively to the teacher, although he did not signal that he was attending in the way that was expected by Balanda.

The Yolngu teachers recognise that the Balanda teachers consider that children are listening only if this is indicated by consistent visual attention and kinesic cues, such as sitting still and facing towards the teacher. When conducting the lesson themselves, Yolngu rarely require children to maintain visual attention or to sit still, unless they are presenting visual material or particularly difficult or complex auditory material.

\section{Conclusions and Recommendations}

At this time the literature on Aboriginal communication and learning is predominantly from a non-Aboriginal perspective; extensive documentation by Aboriginal people of their own viewpoint has yet to occur. This section concludes with comments from Yolngu educators about their interpretation of the processes and goals of classroom learning to provide at least an indication of this perspective, which will hopefully become the predominant framework for understanding the educational needs of Aboriginal children in the future. A Yolngu teacher from Northeast Arnhem Land defined integration of areas of knowledge and negotiation as essential characteristics of Yolngu learning: learning involves cooperation as Yolngu see knowledge as a living thing which people build together (Marika-Mununggiritj, 1991). Another Yolngu from the same community proposed that:

Yolngu children have difficulty learning areas of Balanda knowledge, this is not because Yolngu cannot think, it is because the curriculum in the schools is not relevant for Yolngu children and often these curriculum documents are developed by Balanda teachers who are ethnocentric in their values. An appropriate curriculum for Yolngu is one that is located in the Aboriginal world which can enable children to cross over to the Balanda world. (Yunupingu, 1991: 102)

On the basis of the findings reported in this paper, as well as consultation with teachers and parents in other communities, ${ }^{2}$ we argue that there is a need to 
provide on-going training for classroom teachers and specialist staff working in Aboriginal schools that specifically focuses on:

- developing an understanding of features of Aboriginal learning and communication relevant to the specific region in which they are working (for non-Aboriginal educators);

- how to develop the collaborative approach (between Aboriginal and non-Aboriginal educators) which is essential for effective classroom instruction.

- ESL/EFL-related and hearing loss-related language learning issues (for all educators);

- how to discriminate between communication difference and deficit;

- teaching oral English to students in Aboriginal schools.

Non-Aboriginal teachers frequently comment that a greater knowledge about aspects of Aboriginal communication and learning would enable them to be more effective in the classroom. Both non-Aboriginal and Aboriginal teachers also expressed a need for further training in teaching English as a second/foreign language and in language-learning difficulties related to conductive hearing loss (CHL). This will also assist teachers to identify the sources of a child's communication difficulties which some teachers currently find hard due to their limited knowledge of cultural communication differences and potential communication difficulties related to CHL. A need for training in how to work effectively with assistant teachers was also reported, and observed. When a collaborative approach to planning and teaching is implemented the effectiveness of communication and children's participation is greatly improved (a generalisation based on many classroom observations and teachers' comments). For children with a communication or learning difficulty the role of the TA is even more important in recognising and responding to each individual child's specific needs.

We further recommend that there is a need to address the current inadequacies in the English and literacy programmes (in both bilingual and non-bilingual schools) by focusing on what is currently being done in early primary classes, especially with respect to teaching oral English, and by recognising the language-learning difficulties which can be associated with CHL. Based on the classroom research reported in Lowell (1994) and discussion with teachers in other schools, it appears that the use of a language of instruction in which children do not have sufficient competence is the greatest barrier to successful classroom learning for Aboriginal children. The influence of CHL, particularly on auditory processing and language development, constitutes an additional barrier that reduces the child's opportunity for classroom success even when instruction is in their first language.

To ensure that Aboriginal children's educational potential is achieved, sufficient support must be provided for children to learn the language through which they will be instructed before they are expected to learn through that language (i.e. adequate proficiency in oral English or L1 in a bilingual context). Both communication differences (between L1 and L2) as well as communication difficulties (due to CHL or other causes) must be taken into account when determining the resources and strategies needed. 


\section{A revised model}

Walsh (1996) has provided an elegant and persuasive model which contrasts two differing interactional styles. One, which has perhaps developed to suit busy European lifestyles in the built environment, including the nuclear family home, favours the kind of talk between pairs of people that can be contained or switched off as needed, as opposed to the continuous communal interactional style that Aboriginal people have evolved. Our research lends some support to this model but we would want to add another dimension to it, given that non-Aboriginal teachers showed some preference for focused single-channel talk as opposed to Aboriginal students who seemed comfortable with multi-channel, simultaneous sources of input. Perhaps the model of Western-style talk preferences needs to be refined to include as one of its key dimensions 'single-channel' - which assumes selective attention, versus 'simultaneous', which does not - as well as 'dyadic' and 'contained'. The contrasting interactional style would then be characterised by these three dimensions: 'simultaneous', involving multichannel processing, 'continuous' and 'communal'.

These contrasting communication styles might therefore necessitate differences in processing (for example, simultaneous versus selective attention) which is then reflected in pragmatic differences (such as listening behaviour, where students are 'concentrating with their ears, but not with their eyes').

\section{Correspondence}

Any correspondence should be directed to Dr Brian Devlin, Faculty of Education, Northern Territory University, Darwin, NT 0909, Australia (brian.devlin@ntu.edu.au).

\section{Notes}

1. Non-Aboriginal people are referred to as 'Balanda' by Aboriginal people in Northeast Arnhem Land.

2. Based on a study commissioned by the Northern Territory Department of Education and conducted in four communities in North East Arnhem Land.

\section{References}

Bain, M. (1979) At the interface: The implications of opposing views of reality. MA thesis, Monash University.

Bain, M. and Sayers, B. (1990) Degrees of abstraction and cross-cultural communication in Australia. Paper presented at the Sixth International Conference on Hunting and Gathering Societies, Fairbanks, Alaska.

Boswell, J., Leach, A., Nienhuys, T., Kemp, K. and Matthews, J. (1993) Persistent otitis media in a cohort of Aboriginal infants. What, how and why [abstract]. Australian Journal of Audiology 15 (suppl, April), 36.

Chick, K. (1989) Intercultural miscommunication as a source of friction in the workplace and in educational settings in South Africa. In O. Garcia and R. Otheguy (eds) English Across Cultures; Cultures Across English. A Reader in Cross-Cultural Communication (pp. 139-160). New York: Mouton de Gruyter.

Christie, M. (1984) The classroom world of the Aboriginal Child. PhD thesis, University of Queensland.

Christie, M. and Harris, S. (1985)Communication breakdown in the Aboriginal classroom. In J. Pride (ed.) Cross Cultural Encounters: Communication and Mis-communication (pp. 81-90). Melbourne: River Seine.

Cooke, M. (ed.) (1996) Aboriginal Languages in Contemporary Contexts: Yolngu Matha at Galiwin'ku. Batchelor College, Northern Territory, Australia. 
Cooke, M. and Adone, D. (1994) Yolngu signing — gestures or language? Paper presented at the Australian Linguistic Society Conference, Latrobe University, Melbourne.

Crago, M. (1988) Cultural context in communicative interaction of Inuit children. PhD dissertation, McGill University.

Davidson, G. (1979) An ethnographic psychology of Aboriginal cognitive ability. Oceania 4, 270-4.

Devlin, B. (1986) Language maintenance in a north east Arnhem land settlement. EdD dissertation, Columbia University.

Eades, D. (1982) 'You gotta know how to talk ...': Information seeking in South-East Queensland Aboriginal society. Australian Journal of Linguistics 2, 61-82.

Eades, D. (1991) Aboriginal English: An introduction. Vox 5, 55-61.

Erickson, F. and Mohatt, G. (1982) Cultural organisation of participation structures in two classrooms of Indian students. In G. Spindler (ed.) Doing the Ethnography of Schooling: Educational Anthropology in Action (pp. 132-74). New York: Holt, Reinhart \& Winston.

Erickson, F. and Shultz, J. (1982) The Counsellor as Gatekeeper:Social Interaction in Interviews. New York: Academic Press Inc.

Feagans, L., Sanyal, M., Henderson, F., Collier, A. and Appelbaum, M. (1987) Relationship of middle ear disease in early childhood to later narrative and attention skills. Journal of Pediatric Psychology 12 (4), 581-94.

Friel-Patti, S. and Finitzo, T. (1990) Language learning in a prospective study of otitis media with effusion in the first two years of life. Journal of Speech and Hearing Research 33, 188-94.

Harris, S. (1977) Milingimbi Aboriginal learning contexts. PhD dissertation, University of New Mexico.

Harris, S. (1982) Aboriginal learning styles and the teaching of reading. In J. Sherwood (ed.) Aboriginal Education: Issues and Innovations. Perth: Creative Research.

Harris, S. (1990) Two-way Aboriginal Schooling: Education and Cultural Survival. Canberra: Aboriginal Studies Press.

Hasenstab, M. (1987) Language Learning and Otitis Media. London: Taylor and Francis.

Heath, S. (1983) Ways with Words: Language, Life and Work in Communities and Classrooms. New York: Cambridge University Press.

Howard, D. (1992) Culturally responsive classrooms: A way to assist Aboriginal students with hearing loss in urban schools. In S. Harris and M. Malin (eds) Occasional Papers, No. 1. Darwin: Faculty of Education, NTU.

Imai, M., Anderson, R.C., Wilkinson, I.A.G. and Yi, H. (1992) Properties of attention during reading lessons. Journal of Educational Psychology 84 (2), 160-73.

Kearins, J. (1985) Cross cultural misunderstandings in education. In J. Pride (ed.) Cross Cultural Encounters: Communication and Mis-communication (pp. 65-80). Melbourne: River Seine.

Lowell, A. (1994) Communication and learning in an Aboriginal school: The influence of conductive hearing loss. PhD thesis. University of Sydney.

Malcolm, I. (1979) The Western Australian Aboriginal child and classroom interaction: A sociolinguistic approach. Journal of Pragmatics 3, 305-20.

Malcolm, I. (1982a) Communicative dysfunction in Aboriginal classrooms. In J. Sherwood (ed.) Aboriginal Education Issues and Innovations. Perth: Creative Research.

Malcolm, I. (1982b) Verbal interaction in the classroom. In R. Eagleson, S. Kaldor and I. Malcolm (eds) English and the Aboriginal Child. Canberra: Curriculum Development Centre.

Malcolm, I. (1989) Invisible culture in the classroom: Minority pupils and the principle of adaption. In O. Garcia and R. Otheguy (eds) English Across Cultures: Cultures Across English (pp. 115-35). New York: Mouton de Gruyter.

Malcolm, I. (1994) Aboriginal English inside and outside the classroom. Australian Review of Applied Linguistics 17 (2), 147-80.

Malin, M. (1989) Invisibility in success, visibility in transgression for the Aboriginal child in the urban classroom: Case studies at home and at school in Adelaide. PhD dissertation, University of Minnesota. 
Malin, M. (1990) Why is life so hard for Aboriginal students in urban classrooms? The Aboriginal Child at School 18, 9-29.

Marika-Mununggiritj, R. (1991) How can Balanda (white Australians) learn about the Aboriginal world? Ngoonjook, Bachelor Journal of Aboriginal Education 6, 17-26.

McConvell, P. (1991)Cultural domain separation: Two-way street or blind alley? Stephen Harris and the neo-Whorfians on Aboriginal education. Australian Aboriginal Studies 1, 13-24.

Nienhuys, T., Boswell, J. and McConnel, F. (1994) Middle ear measures as predictors of hearing loss in Australian Aboriginal schoolchildren. International Journal of Pediatric Otorhinolaryngology 30, 15-27.

Northern Territory Department of Education (1989) Aboriginal Children: Some Things They Know About Before They Come to Preschool. Maningrida: Maningrida Literature Production Centre.

Philips, S. (1972) Participant structures and communicative competence: Warm Springs children in community and classroom. In C. Cazden, V. John, and D. Hymes (eds) Functions of Language in the Classroom (pp. 370-94). New York: Teachers College Press, Columbia University.

Philips, S. (1983) The Invisible Culture: Communication in Classroom and Community on the Warm Springs Indian Reservation. New York: Longman.

Quinn, S. (1988) Conductive hearing loss in Aboriginal children in the Northern Territory. Paper presented at the 8th National Conference of the Audiological Society of Australia, Perth, Western Australia.

Saville-Troike, M. and Kleifgen, J. (1989) Culture and language in classroom communication. In O. Garcia and R. Otheguy (eds) English Across Cultures; Cultures Across English. New York: Mouton de Gruyter.

Silva, A., Chalmers, D. and Stewart, I. (1986) Some audiological, psychological, educational and behavioural characteristics of children with bilateral otitis media with effusion: A longitudinal study. Journal of Learning Disabilities 19, 165-9.

Teele, D., Klein, J., Chase, C., Menyuk, P., Rosner, B. and The Greater Boston Otitis Media Study Group (1990) Otitis media in infancy and intellectual ability, school achievement, speech and language at age 7 years. Journal of Infectious Diseases 162, 685-94.

Walker, R. (1983) The English used by Aboriginal children. Australian Review of Applied Linguistics 6 (1), 64-75.

Walsh, M. (1996) Cross-cultural communication problems in Aboriginal education. A talk given at a North Australia Research Unit seminar on 23 May 1996.

Webber, D. (1978) Interpersonal behaviour in relation to Aboriginal programs. Australian Journal of Social Issues 13 (1), 61-72.

Yunupingu, B. (1991) A plan for Ganma research. In Aboriginal Pedagogy: Aboriginal Teachers Speak out. Blekbala wei, Deme nayin, Yolngu Rom, Ngini Nginingawula, Ngawurranungurumagi (pp. 98-106). Geelong: Deakin University Press. 